\title{
EDITORIAL 13. ČÍSLA
}

\section{7. prosince 2020}

\author{
JAROSLAV GoTTFRIED, HYNEK CÍGLER \\ Katedra psychologie, FSS MU 1
}

Vážené čtenářky, vážení čtenáři,

př́żnivci kvalitních psychodiagnostických metod.

Jakkoliv byl tento rok pro každého náročný, komplikace se bohužel nevyhnuly ani našemu časopisu. Vzhledem k menšímu objemu nových příspěvků a o něco delšímu průběhu recenzních řízení vydáváme letos pouze jedno nové číslo, namísto obvyklých dvou. Troufáme si však říci, že změny jsou patrné pouze v kvantitě, nikoliv v kvalitě. Věříme, že i v tomto čísle naleznete příspěvky, které vás zaujmou a obohatí.

Hned prvním z nich je studie Lenky Pivodové, Petry Daňsové a Lenky Lacinové, ve které autorky provedly důkladnou pilotáž a validizaci nového Dotazníku zmatení rolí pro adolescenty. Ten ocení především vývojoví psychologové pro výzkumné účely, přičemž ale není vyloučeno, že metoda by se v budoucnu mohla uplatnit například v poradenské praxi. Psychometricky a kvantitativně orientovaným čtenářům může zase přijít vhod přehledná recenze na sborník Handbook of Item Response theory van der Lindena od našeho editora Hynka Cíglera. Pokud tedy uvažujete o rozšíření svých obzorů ohledně teorie odpovědi na položku, můžete tuto recenzi brát jako dobrý tip. Zároveň vám v tomto čísle přinášíme již tradičně i nové recenze vybraných psychodiagnostických metod. Tentokrát na vás čeká recenze známého osobnostního inventáře NEO-3 od Dominika Kováře a Barbory Břežné a recenze dotazníku interpersonálních vztahových potřeb FIRO-B od Alexandry Pospíšilové a Andrey Sandanusové. Přečtení recenzí vám vřele doporučujeme, zvláště pokud se o některou z těchto metod zajímáte nebo $s$ ní dokonce pracujete.

Závěrem vás chceme upozornit na probíhající výzkum pod hlavičkou Evropské federace psychologických asociací (EFPA) o přístupu k psychologické diagnostice, na kterém se podílejí prof. Tomáš Urbánek a dr. Hynek Cígler z redakce našeho časopisu. Průzkum se mimo jiné zaměřuje i na četnost využívání různých diagnostických metod; respondenti mají možnost hodnotit i jejich kvalitu. Dotazník najdete na tomto odkaze: https://masaryk.eu.qualtrics.com/jfe/form/SV_6s8TskFWJNPhX9j.

\footnotetext{
${ }^{1}$ Katedra psychologie, Fakulta sociálních studií Masarykovy univerzity, Joštova 10, 60200 Brno
} 
Druhou podstatnou informací je termín konání konference Psychologická diagnostika Brno 2021. Konání bylo přeloženo kvůli pandemii COVID-19 z letošního roku na příští, termín však zůstal prakticky zachován: je jím 22.-23. duben 2021. Tento termín se již měnit nebude a vpř́padě nepříznivé epidemiologické situace konference proběhne on-line formou. Registrace př́spěvků i běžných účastníků je stále otevřena; více informací naleznete na https://psychodiagnostika.fss.muni.cz.

Přejeme vám zajímavé čtení a příjemné vánoční svátky!

Hynek Cígler a Jaroslav Gottfried, editoři časopisu

v Brně 17. 12. 2020 